\title{
Sistem Pengisian Akumulator Dengan DC Chopper Menggunakan Metoda Arus Konstan Berbasis Mikrokontroller Atmega8535
}

\author{
Elfizon \\ Teknik Elektro FT UNP \\ Universitas Negeri Padang \\ Padang, Indonesia \\ elfizon@ft.unp.ac.id
}

\author{
Aslimeri \\ Teknik Elektro FT UNP \\ Universitas Negeri Padang \\ Padang, Indonesia \\ aslimeri@ ft.unp.ac.id \\ Fadhil Adra \\ Teknik Elektro FT UNP \\ Universitas Negeri Padang \\ Padang, Indonesia \\ fadhiladra@ft.unp.ac.id
}

\author{
Asnil \\ Teknik Elektro FT UNP \\ Universitas Negeri Padang \\ Padang, Indonesia \\ Asnil@ft.unp.ac.id
}

\begin{abstract}
This paper aims to design an accumulator filling system with a DC Chopper using a constant current method. DC Chopper (Buck Converter) on this tool uses MOSFET as a switching component that produces PWM (Pulse Width Modulation) waves from the ATMega8535 Microcontroller which is set with the Basic Compiler (BASCOM-AVR) programming language, so that it can determine the amount of current and output voltage needed for charging accumulator. Test Results, accumulating the accumulator is carried out by a constant current method by keeping the current at its limit of 0.4 Ampere to reach the maximum voltage on the accumulator. Accumulator filling is successfully stopped by the work of MOSFET which is made inactive when the voltage on the accumulator is detected at $\mathbf{1 3 . 2}$ Volts and reactivated when the voltage is detected at 7 Volts, by regulating the pulse wave ignition (PWM) that has been set in the ATMega8535 Microcontroller program. Charging takes 270 minutes / 4.5 hours.
\end{abstract}

Key Words- Akumulator, Buck konverter, ATMega8535, MOSFET, sensor tegangan, ACS712.

\section{PENDAHUluan}

Akumulator dapat mengacu kepada baterai, kapasitor, atau lainnya yang berkaitan dengan suatu benda yang dapat menyimpan muatan listrik. Sifat yang menarik dari akumulator adalah dapat diisi kembali. Alat pengisian aki biasanya memakai trafo dan dioda bridge saja. Arus pengisiannya tidak stabil yang dapat merusak aki. Biasanya pengisian akumulator dihentikan dengan cara manual atau memprediksi akumulator itu telah penuh dengan melihat dari perkiraan waktu pengisiannya saja. Jika akumulator telah mencapai tegangan maksimumnya tetapi tetap dilakukan pengisian, maka akan menimbulkan pemborosan energi listrik serta terjadi pemanasan berlebihan yang akan memperpendek umur akumulator, (Andri 2010).

Dalam hal ini penulis merancang alat pengisian akumulator dengan $D C$ Chopper menggunakan metoda arus konstan. DC Chopper yang digunakan adalah buck converter karena memiliki efisiensi yang tinggi dan sederhana, serta menurunkan tegangan tanpa harus menghilangkan daya yang relatif besar. Metoda Arus Konstan berfungsi untuk menghasilkan arus yang sesuai dengan kapasitas baterai dan menjaga arus pengisian tetap konstan selama pengisian berlangsung. Lamanya waktu yang dibutuhkan untuk pengisian bergantung pada besar arus pengisian. Baterai telah terisi penuh bila tegangan baterai sudah mencapai nilai maksimumnya.

Akumulator merupakan salah satu komponen penting pada kendaraan bermotor, mobil, motor, dan sebagainya. Akumulator dapat dijadikan sebagai penyimpan listrik dan penstabil tegangan serta arus listrik kendaraan. Ketika aki dipakai, terjadi reaksi kimia yang mengakibatkan endapan pada anode (reduksi) dan katode (oksidasi). Akibatnya, dalam waktu tertentu antara anoda dan katoda tidak ada beda potensial, artinya aki menjadi kosong (Nasrah, 2014).

Baterai aki terdiri dari beberapa sel. Baterai aki 12 Volt, terdiri dari 6 sel. Batas tegangan satu sel umumnya mulai dari $2.30 \mathrm{~V}$ sampai $2.45 \mathrm{~V}$. Jadi baterai aki 12 Volt, tegangan sebenarnya adalah antara $13.8 \mathrm{~V}-14.7$ Volt. Kondisi baterai aki tergantung dari suhu. Suhu tinggi menyebabkan baterai cepat rusak. Pada saat charging baterai pada suhu ruangan melebihi 30 derajat celcius, tegangan yang direkomendasikan adalah $2.35 \mathrm{~V} / \mathrm{sel}$. Pada saat charging, dan suhu ruangan tetap dibawah 30 derajat Celcius, tegangan charger untuk masingmasing sel disarankan 2.40 sampai 2.45 Volt.

\section{A. Konverter $D C-D C$}

Penulis dapat memperoleh Konverter DC - DC, yaitu:

1. Buck Converter, menghasilkan tegangan keluaran lebih kecil dibandingkan tegangan masukan.

2. Boost Converter, menghasilkan tegangan keluaran lebih besar dibandingkan tegangan masukan.

3. Buck - Boost Converter, menghasilkan tegangan yang lebih kecil atau lebih besar dari dibandingkan tegangan masukan. Regulator ini juga disebut regulator pembalik.

4. Boost - Buck / Cuk Converter, menghasilkan tegangan keluaran yang lebih kecil atau lebih besar dibandingkan 
tegangan masukan, tetapi polaritas tegangan keluaran berlawanan dengan polaritas tegangan masukan.

Konverter DC - DC yang digunakan pada tugas akhir ini adalah Buck Konverter. Buck Konverter adalah konverter yang bekerja sebagai Step-Down, yaitu bekerja menurunkan tegangan DC dengan mengatur besarnya switching Dutycycle. Duty cycle (k) dapat divariasikan dari 0 sampai 1 dengan bervariasi menurut $t_{1}, \mathrm{~T}$, atau $\mathrm{f}$. Maka tegangan keluaran $V$ " dapat divariasikan dari 0 sampai $V_{s}$ dengan mengatur $\mathrm{k}$.

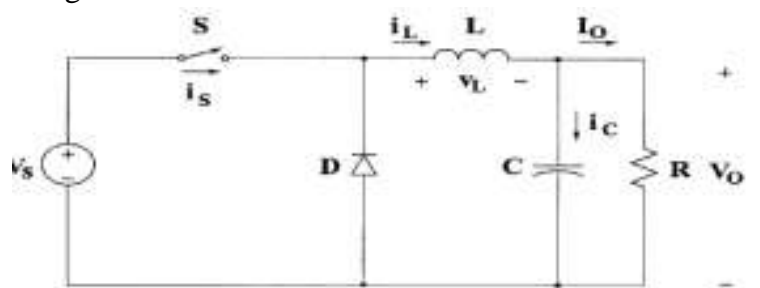

Gambar 1. Rangkaian Buck Konverter (Rashid,1999:248)

\section{B. Mikrokontroller ATMega8535}

Mikrokontroler adalah sebuah sistem komputer lengkap dalam satu chip. Mikrokontroler lebih dari sekedar sebuah mikroprosesor karena sudah terdapat atau berisikan ROM

(Read-Only Memory), RAM (Read-Write Memory), beberapa port masukan maupun keluaran, dan beberapa peripheral seperti pencacah/pewaktu, ADC (Analog to Digital converter), DAC (Digital to Analog converter) dan serial komunikasi.

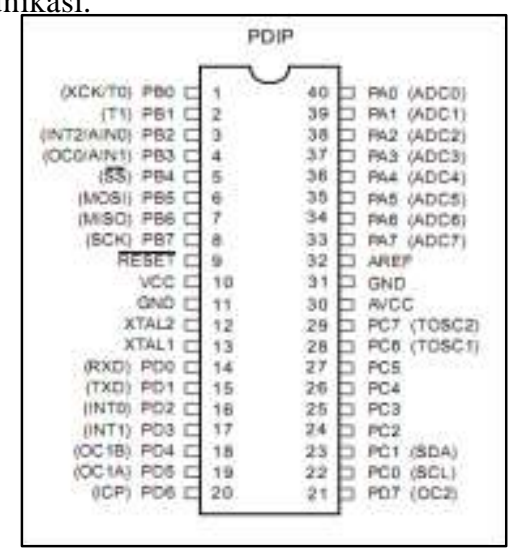

Gambar 2. Konfigurasi ATMega8535

(Bachtiar Efendi,2014: 14)

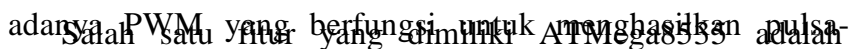
pulsa yang dapat diatur lebarnya berdasarkan penggunaan Timer / Counter yang sudah ada. Menurut Syahrul(2012:442) "PWM merupakan teknik mengubahubah lebar sinyal listrik gelombang kotak dalam amplitudo yang konstan dengan tujuan untuk mendapatkan nilai tegangan rata-rata yang berbeda".

Dengan cara mengatur lebar pulsa "on" dan "off" dalam satu perioda gelombang melalui pemberian besar sinyal referensi output dari suatu PWM akan didapat duty cycle yang diinginkan. Duty cycle dari PWM dapat dinyatakan sebagai berikut.

$$
\text { Duty cycle }=\frac{\$ \% \&}{\$ \% \&} \times 100 \%
$$

\section{Arus}

Sensor Arus yang digunakan adalah Sensor Arus Efek Hall ACS712. Hall Effect Allegro ACS712 merupakan sensor yang presisi sebagai sensor arus AC atau DC dalam pembacaan arus didalam dunia industri, otomotif, komersil dan sistem $\quad-\quad$ sistem komunikasi.

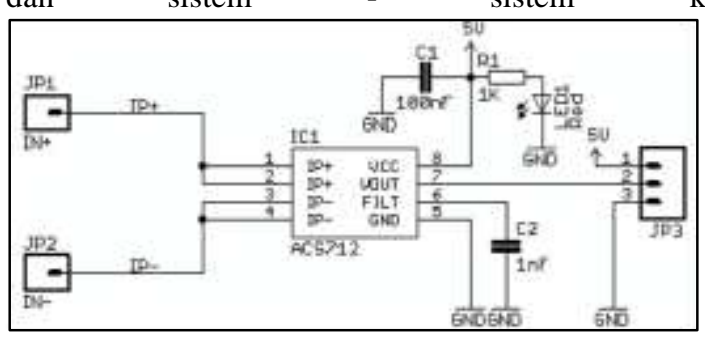

Gambar 3. Rangkaian Sensor ACS712

\section{Sensor Tegangan}

Sensor Tegangan menggunakan Rangkaian Pembagi an. Rangkaian Pembagi Tegangan berfungsi untuk Tegangkan tegangan sampai batas kemampuan pembacaan menurpada AVR Mikrokontroller dan digunakan sebagai ADC eksi tegangan yang terdapat pada beban.

pendet gkaian Pembagi Tegangan tersebut adalah sebagai Ran' berikut

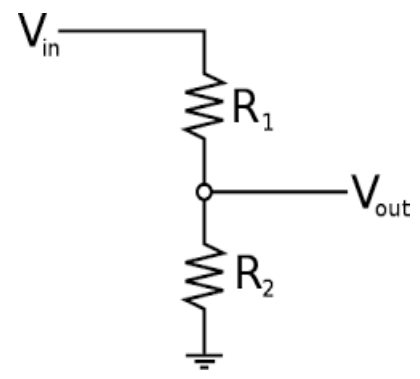

Gambar 4. Rangkaian Pembagi Tegangan

\section{$D$}

E. LCD (Liquid Cristal Display) adalah salah satu LC nen elektronika yang berfungsi sebagai media kompBil data yang sangat efektif dalam suatu sistem pelkafronik.

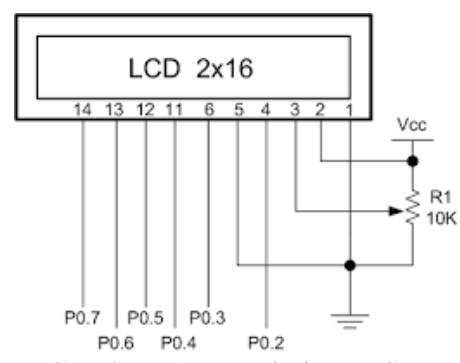

Gambar 5. Rangkaian LCD

(Franky, 2009: 1) 


\section{METODOLOGI PERANCANGAN}

\section{A. Blok Diagram}

Blok diagram merupakan gambaran dasar dari rangkaian sistem yang akan dirancang, dimana setiap diagram blok memiliki fungsinya masing-masing. Adapun diagram blok dari sistem yang dirancang adalah seperti yang diperlihatkan pada gambar berikut.

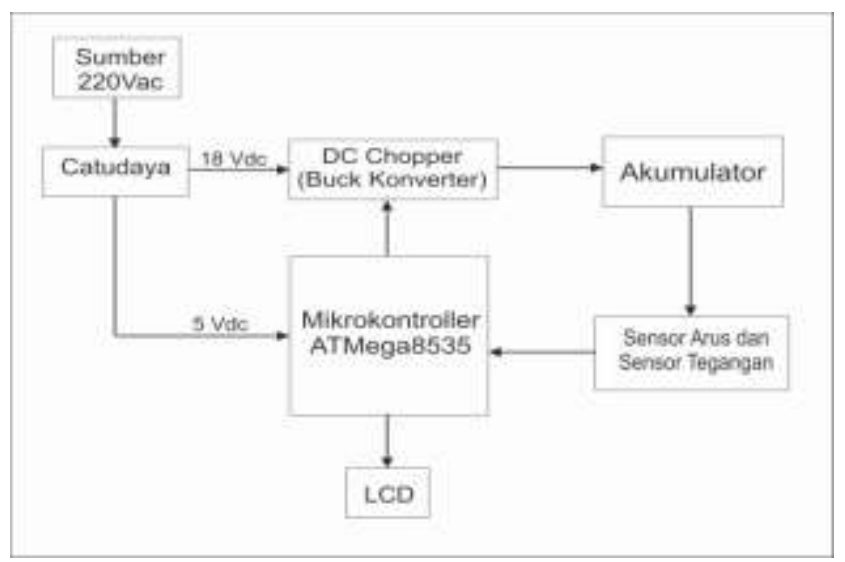

Gambar 6. Blok Diagram Sistem-Pengisian Akumulator Otomatis

\section{B. Prinsip Kerja Alat}

Prinsip kerja alat iniberawal dari sumber 1 fasa PLN sebesar 220 Vac ditumkan melalui Trafo Step-Down menjadi tegangan 18 Vacpada sisi sekundernya. Tegangan tersebut disearahkan melalui rangkaian catudaya yang terdapat penyearah (rectifier) didalamnya menjadi tegangan $18 \mathrm{Vdc}$ dan $5 \mathrm{Vdc}$. Tegangan $5 \mathrm{Vdc}$ disini digunakan sebagai sumber tegangan pada Mkrokontroller ATMega8535, LCD, Sensor Arus dan Sensor Tegangan. Sedangkan, tegangan 18 Vdc akan menjadi masukan pada Buck Konverter.

Pada rangkaian $b^{\text {uck }}$ converter ini menggunakan MOSFET sebagai switching. Untuk mengaktifkan gate MOSFET, dipakai Mik rokontroller ATMega8535 yang mengirim sinyal ke pin A DC sebagai input PWM pada kaki gate MOSFET tersebut. Keluaran dari Mikrokontroller ATMega8535 ini terhubung ke Rangkaian Driver sebagai penguatan pembangkitan gelombang pulsa. Rangkaian Driver digunakan sebagai kopling antara mikrokontroller dengan konverter DC ka rena mikrokontroler tidak mampu mengendalikan konverter secara langsung.

Dengan menggunakan teknik PWM pada Mikrokontrolller ATMega8535 dalam pengendalian switching rangkaian buck Konverter, maka nilai duty cycle dapat ditentukan. Setelah tegangan sesuai dengan nilai duty cycle yang diinginkan, maka tegangan dapat dimanfaatkan untuk pengisian akumulator.

Melalui Rangkaian Buck Konverter tegangan yang bersumber dari penyearah $18 \mathrm{~V}$ diturunkan menjadi $12 \mathrm{~V}$, keluaran dari Buck Konverter tersebut terhubung ke Akumulator. Selanjutnya Akumulator pada alat ini terhubung ke Sensor Tegangan dan Sensor Arus yang berfungsi sebagai pendeteksi tegangan dan arus yang terdapat pada akumulator tersebut. Dengan memanfaatkan rangkaian pembagi tegangan, tegangan yang terdeteksi dibaca dengan ADC internal dari AVR Mikrokontroller ATMega8535 yang kemudian dikonversi ke tegangan digital oleh ADC internal, begitu juga dengan sensor arus dengan menggunakan Sensor Arus ACS712. Hasil pembacaan dari sensor ini akan diolah oleh mikrokontroller dan selanjutnya ditampilkan ke LCD.

Jika tegangan terdeteksi $13.2 \mathrm{Vdc}$, maka MOSFET akan berhenti bekerja / tidak aktif. Karena PWM dari Mikrokontroller dimatikan, yang telah diatur pada program Mikrokontroller ATMega8535, dan pengisian akumulator akan berhenti. Apabila tegangan terdeteksi sebesar $7 \mathrm{Vdc}$ maka MOSFET akan tetap bekerja/aktif, karena telah diatur juga pada program Mikrokontroller ATMega8535, sehingga pengisian akumulator akan tetap berjalan. Dan status dari pengisian akan ditampilkan pada LCD.

\section{Perancangan Hardware}

1. Perancangan Rangkaian Catu Daya

Rangkaian catu daya yang digunakan pada tugas akhir ini menggunakan trasformator stepdown yang digunakan untuk menurunkan tegangan AC ke tegangan DC.

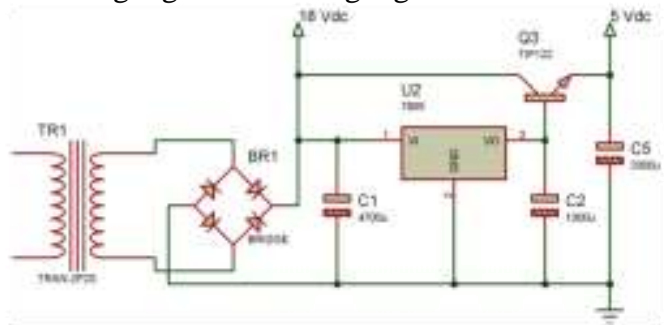

Gambar 7. Rangkaian Catu Daya

\section{Perancangan DC Chopper (Buck Konverter)}

$D C$ Chopper yang digunakan pada tugas akhir ini adalah DC Chopper tipe buck konverter yang mempunyai kara kteristik tegangan keluaran lebih kecil dari tegangan

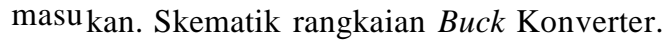

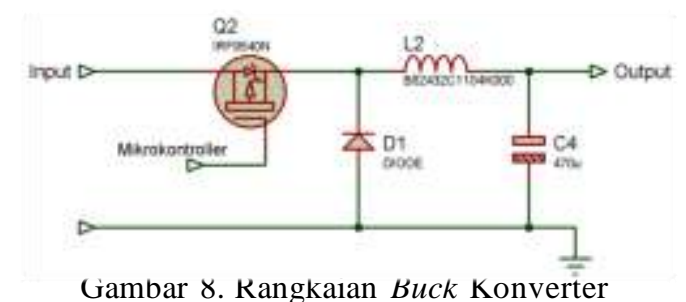

Spesifikasi Buck Konverter yang akan dibuat adalah sebagai berikut:

Tegangan masukan $\quad: 18 \mathrm{~V}$

Tegangan keluaran $\quad: 12 \mathrm{~V}$

Frekuensi Switching $\quad: 40 \mathrm{kHz}$

Arus $\quad: 0.4 \mathrm{~A}$

1) Perhitungan Duty Cycle

$$
\mathrm{D}=\frac{/ 0}{/ 1}=\frac{23}{24}=0.6
$$

2) Perhitungan Nilai Induktor

Nilai Induktor yang digunakan sesuai perancangan untuk rangkaian buck konverter disini adalah:

$$
\Delta=0.3
$$

$$
\Delta l=0.30 .4 \mathrm{~A}=0.12 \mathrm{~A}
$$




$$
\begin{aligned}
& L=\frac{1}{F_{3}} x\left(-V_{n} x\right) \frac{V_{n}}{V_{0}} \times \frac{1}{\Delta !} \\
& \begin{array}{l}
\frac{1}{40000}(\quad) \frac{12}{18} \frac{1}{0.12} \frac{72}{86400} \\
=0.00083 \mathrm{H}=0.83 \mathrm{mH}
\end{array}
\end{aligned}
$$

3) Perhitungan Nilai Kapasitor

$$
\begin{aligned}
& \Delta V=0.1 \% \text {. } \\
& \Delta V=0.1 \% 12=0.012 \mathrm{~V} \\
& c=\frac{\Delta}{8 V^{\prime} \cdot} \\
& 0.12 \quad 0.12 \\
& =31.25 \mu \mathrm{F}
\end{aligned}
$$

Namun untuk mengurangi noise, kapasitor yang dipasang adalah $470 \mu \mathrm{F}$.

\section{Perancangan Software}

Diagram alir ini berguna untuk menentukan langkahlangkah atau alur pembuatan suatu alat. Diagram alir atau Flowchart alat pengisian akumulator otomatis ini dapat dilihat pada gambar berikut ini.

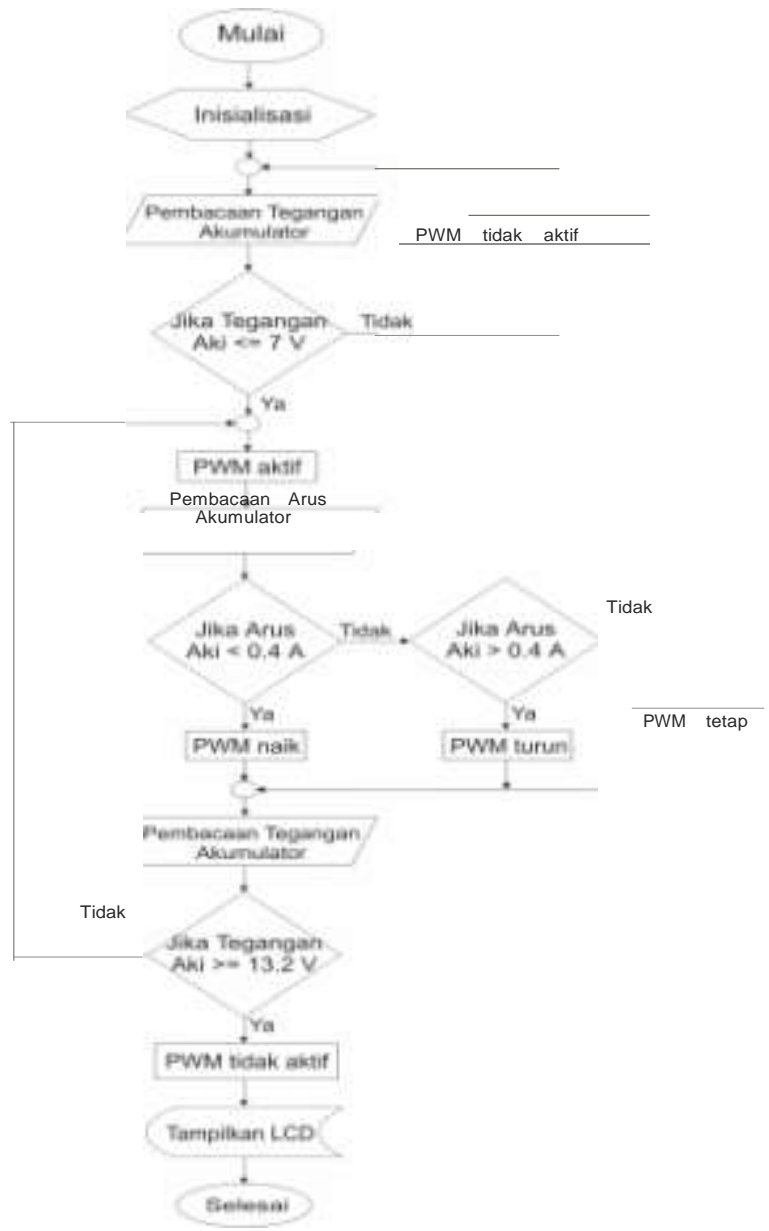

Gambar 8. Flowchart Sistem Alat Pengisian Akumuator Otomatis

\section{PENGUJIAN DAN ANALISA}

A. Rangkaian Mikrokontroler ATMega8535

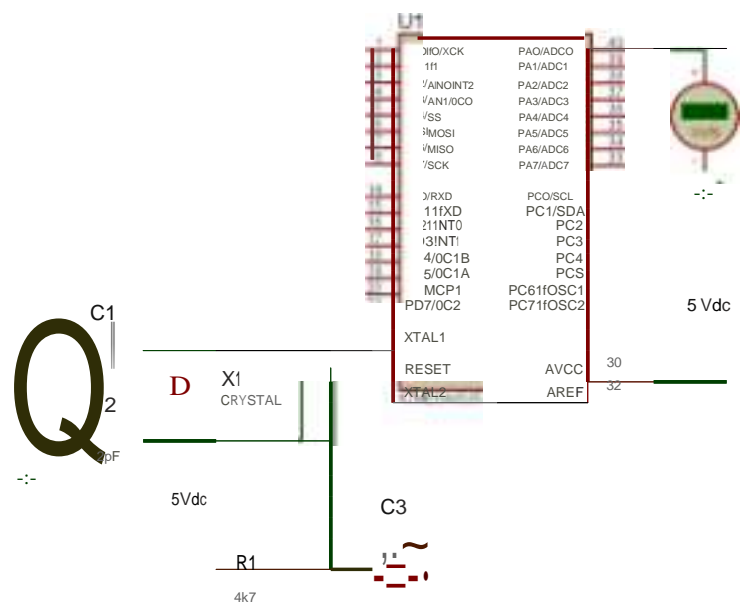

Gambar 10. Pengukuran Rangkaian Mikrokontroller ATMega8535

Rangkaian sistem minimum mikrokontroler ATMega 8535 ini dapat diukur dengan cara menghubungkan rangkaian dengan sumber catu daya $5 \mathrm{Vdc}$, Pengukuran tegangan dilakukan terhadap parameter logika ' 0 ' dan logika ' 1 ' pada port I/O mikrokontroler ATMega 8535.

Tabel 1. Hasil Pengukuran Tegangan pada Rangkaian Mikrokontroller ATMega8535

\begin{tabular}{c|c}
\hline Logika Port & Tegangan pada Atmega8535 \\
\hline Low (0) & $0.2 \mathrm{Vdc}$ \\
High (1) & $4.9 \mathrm{Vdc}$ \\
\hline
\end{tabular}

Mikrokontroller berkerja pada kondisi logika yaitu kondisi low (0) dimana tegangan yang terbaca pada instrumen pengukuran tegangan didapatkan tegangan port sebesar 0.2 Vdc, yang berarti sistem dalam batas ideal. Logika yang kedua yaitu kondisi high (1) dimana tegangan yang terbaca pada instrumen pengukuran tegangan didapatkan tegangan port sebesar $4.9 \mathrm{Vdc}$, yang berarti sistem masih dalam batasan ideal karena mikrokontroler ATmega 8535 memiliki tegangan kerja antara $4.5 \mathrm{Vdc}$ hingga $5.5 \mathrm{Vdc}$.

\section{B. Rangkaian Buck Konverter}

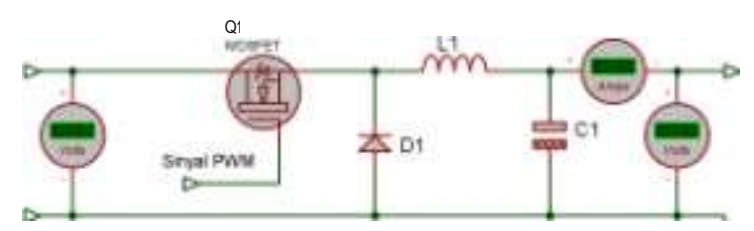

Gambar 9. Pengukuran Rangkaian Buck Konverter Rangkaian Buck Konverter ini dapat diukur dengan cara menghubungkan rangkaian dengan sumber catu daya $18 \mathrm{Vdc}$. Rangkaian buck konverter digunakan sebagai sumber tegangan dan arus dari pengisian akumulator. Hasil pengujian rangkaian buck konverter dapat dilihat sebagai berikut. 
Tabel 2. Hasil Pengukuran Tegangan dan Arus pada Rangkaian Buck Konverter

\begin{tabular}{r|c|c|c}
\hline No & $\begin{array}{c}\text { Titik } \\
\text { Pengukuran }\end{array}$ & $\begin{array}{c}\text { Hasil } \\
\text { Seharusnya }\end{array}$ & $\begin{array}{c}\text { Hasil yang di } \\
\text { peroleh }\end{array}$ \\
\hline 1 & Tegangan input & $18 \mathrm{Vdc}$ & $17.5 \mathrm{Vdc}$ \\
\hline 2 & Tegangan output & $12 \mathrm{Vdc}$ & $16.8 \mathrm{Vdc}$ \\
\hline 3 & Arus Output & $0.4 \mathrm{~A}$ & $0.42 \mathrm{~A}$ \\
\hline
\end{tabular}

Dari perhitungan di atas dapat dilihat bahwa persentase kesalahan dari tegangan keluaran buck konverter sangatlah besar yaitu 40\%, karena pada perancangan alat ini menggunakan metoda aru $_{\mathrm{s}}$ konstan sehingga besar tegangan keluaran yang didapatkan tergantung kapasitas tegangan beban yang dipasang / $\mathrm{ak}_{\text {umulator. }}$

Sedangkan untuk pen gukuran arus yang terbaca terjadi penyimpangan sebesar $5 \%$. Penyimpangan tersebut masih dalam toleransi, karena $m_{\text {aksimum error dari sensor ACS712 }}$ adalah $5 \%$.

Berdasarkan dari kondisi pengukuran dan pengujian diatas, maka rangkaian buck converter telah dapat berkerja dengan baik.

\section{Pengujian Gelombang Keluaran PWM (Pulse Width Modulation)}

Sinyal PWM dihasilkan dari mikrokontroller pada port D5 dan terhubung ke Gate MOSFET pada rangkaian buck konverter. Pengujian ini dapat dilakukan dengan melihat bentuk gelombang PWM dari keluaran pin mikrokontroller port D5 dengan menggunakan oscilloskop.

Bentuk Gelombang Keluaran PWM seperti gambar di bawah ini.

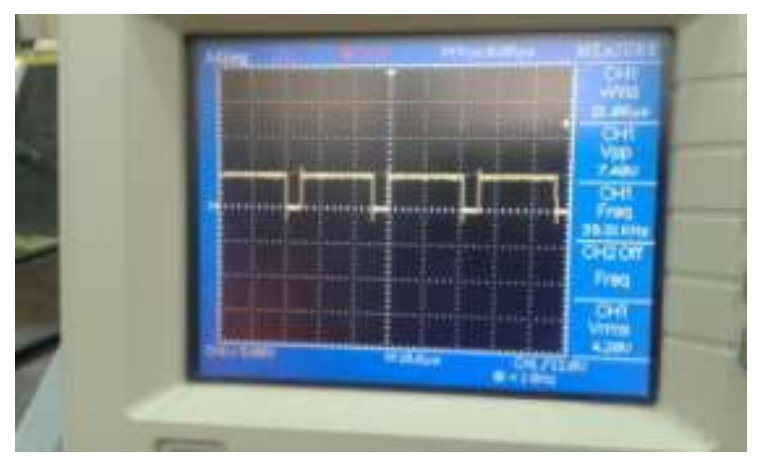

Gambar 11. Bentuk Gelombang PWM yang dihasilkan Mikrokontroller

Dari gambar diatas merupakan bentuk gelombang PWM yang dihasilkan mikrokontroller pada Port D5.Gelombang keluarannya berbentuk sinyal kotak dengan amplitudo positif.

\section{Pengujian Rangkaian}

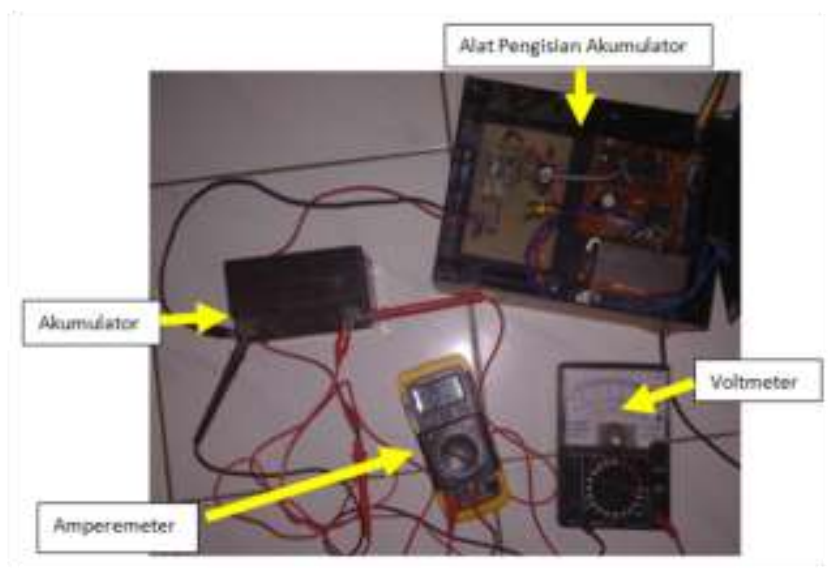

Gambar 12. Proses Pengisian Akumulator

Untuk pengujian ini yang dilakukan adalah pengujian charging (pengisian) akumulator dengan kapasitas $12 \mathrm{~V} / 3.5 \mathrm{Ah}$. Indikator yang diiukur pada pengujian ini adalah hubungan antara arus pengisian, tegangan akumulator, dan waktu pengisian pada akumulator

Berikut merupakan hasil dari pengisian akumulator.

Tabel 3. Hasil Pengujian Pengisian Akumulator

\begin{tabular}{c|c|c}
\hline $\begin{array}{c}\text { Waktu } \\
\text { Pengisian }\end{array}$ & $\begin{array}{c}\text { Tegangan } \\
\text { Akumulator }(\mathrm{V})\end{array}$ & Arus (A) \\
\hline 0 menit & 7.2 & 0.44 \\
\hline 15 menit & 9.9 & 0.44 \\
\hline 30 menit & 10.2 & 0.46 \\
\hline 45 menit & 10.4 & 0.45 \\
\hline 60 menit & 10.7 & 0.45 \\
\hline 75 menit & 10.8 & 0.45 \\
\hline 90 menit & 10.8 & 0.45 \\
\hline 105 menit & 10.9 & 0.46 \\
\hline 120 menit & 10.9 & 0.46 \\
\hline 135 menit & 10.9 & 0.45 \\
\hline 150 menit & 11 & 0.46 \\
\hline 165 menit & 11.1 & 0.46 \\
\hline 180 menit & 11.2 & 0.47 \\
\hline 195 menit & 11.2 & 0.46 \\
\hline 210 menit & 11.9 & 0.46 \\
\hline 225 menit & 12.2 & 0.44 \\
\hline 240 menit & 12.5 & 0.45 \\
\hline 255 menit & 12.6 & 0.44 \\
\hline 270 menit & 13.2 & \\
\hline
\end{tabular}

Pada Tabel 3 dapat kita lihat bagaimana kondisi tegangan akumulator ketika melakukan pengisian dengan metoda arus konstan. Nilai tegangan yang terukur terlihat naik seiring dengan berjalannnya waktu pengisian. Hal ini menunjukkan bahwa kapasitas listrik di dalam akumulator telah terisi 
sampai kondisi penuh sebesar 13.2 Volt. Pengisian berlangsung selama 270 Menit / 4,5 jam.

\section{KESIMPULAN DAN SARAN}

\section{A. Simpulan}

Dari perencanaan, pembuatan dan pengujian alat serta analisa yang sudah dilakukan maka dapat disimpulkan bahwa.

a. Alat pengisian akumulator ini aktif saat tegangan akumulator terdeteksi sebesar 7 Volt dan berhenti saat tegangan akumulator teredeteksi sebesar 13.2 Volt. Apabila tegangan akumulator di awal pengisian terdeteksi melebihi dari 7 Volt alat ini tidak aktif, dan saat akumulator di lepaskan dari alat maka akan tampil indikator "ACCU Tidak Terpasang" pada LCD.

b. Metode arus konstan dilakukan dengan menjaga arus pengisian tetap stabil sebesar 0.4 Ampere dengan mengatur penyalaan sinyal PWM yang bekerja apabila arus melebihi nilai 0.4 Ampere maka PWM diturunkan, sebaliknya jika arus terukur kurang dari 0.4 Ampere maka PWM dinaikkan. Dan jika arus yang terukur sebesar 0.4 Ampere maka PWM bernilai tetap.

c. Lamanya pengisian akumulator dengan metoda arus konstan ini berlangsung selama 270 menit atau 4.5 jam. Pengisian akumulator lebih cepat mencapai tegangan maksimalnya dibandingkan dengan indikator yang terdapat pada akumulator tersebut yaitu dengan pengisian normal selama 5 - 10 jam.

\section{B. Saran}

Dalam makalah ini, penulis menemukan beberapa kekurangan yang terdapat pada sistem ini. Untuk memperbaiki kekurangan dalam menyempurnakan sistem ini, maka penulis memberikan saran agar didapatkan hasil yang lebih sempurna, diantaranya.

a. Besarnya persentase kesalahan pada tegangan keluaran rangkaian buck konverter yaitu 40\%, sebaiknya lebih diperkecil sehingga tegangan yang dibutuhkan untuk pengisian akumulator sebanding dengan kapasitas akumulator yang dipakai.

b. Pengisian akumulator dengan metoda arus konstan ini besarnya arus yang dipakai bisa divariasikan sesuai dengan kapasitas akumulator yang akan diisi, sehingga alat ini tidak terbatas dengan satu kapasitas akumulator saja.

\section{REFERENSI}

[1] Afrie, Setiawan. 2011. 20 Aplikasi Mikrokontroler ATMEGA 8535 dan ATMEGA 16 menggunakan BASCOM - AVR. Yogyakarta : Andi.

[2] Andri, Helly. 2010. Rancang Bangun System Battery Charging Automatic. Depok: Universitas Indonesia.

[3] Andri, Rahmadhani. 2007. Tutorial Pemrograman Mikrokontroler AVR (Bagian I). Bandung: Laboratorium Elektronika dan Instrumentasi Fisika ITB.

[4] Andrianto, Heri. 2013. Pemrograman Mikrokontroler AVR Atmega 16 menggunakan bahasa C. Bandung: Informatika.Bachtiar, Efendi. 2014. Dasar Mikrokontroler Atmega8535 dengan CAVR. Yogyakarta: Deepublish.

[5] Choi, Byungcho. 2013. Pulsewidth Modulated DC-To-DC Power Conversion, Canada: IEEE Press.
[6] Eko, Setiawan. 2011. Penggunaan Konverter Jenis Buck Dengan Pemutus Tegangan Otomatis Untuk Pengisi Akumulator. Semarang: Universitas Diponegoro.

[7] Elfizon. 2017. Sistem Kendali Governor Pembangkit Listrik Tenaga Diesel Berbasis Mikrokontroller, Prosiding Seminar Nasional Teknik Elektro (FORTEI 2017) ISBN 978-602-6204-24-0 Fakultas Teknik Universitas Negeri Gorontalo, 18 Oktober 2017.

[8] Franky. 2009. Aplikasi LCD pada Mikrokontroler, (online), https://frankyoneza. wordpress.com/2009/08/05/aplikasi-lcd-padamikrokontroller/, diakses tanggal 17 Maret 2017.

[9] Holmes, D. Grahame \& Lipo, Thomas A. 2003. Pulse Width Modulation For Power Converter - Principle and Practice. New Jersey :IEEE Series On power Engineering.

[10] M.Ary Heryanto dan Wisnu Adi P. 2008. Pemograman Bahasa C untuk Mikrokontroler Atmega 8535. Yogyakarta: Andi Offset.

[11] Rashid, Muhammad. 1999. Elektronika Daya. Jakarta: Prenhallindos.

[12] Rashid, Muhammad. 2001, Power Electronics. Academic Press,USA.

[13] Zuhal, Zhanggischan. 2004. Prinsip dasar elektroteknik, Jakarta: PT. Gramedia Pustaka Utama. 